\title{
The Timeliness of Direct Democracy in the EU - The Example of Nuclear Energy in the EU and the Institutionalisation of the European Citizens' Initiative in the Lisbon Treaty ${ }^{*}$
}

\section{Christian Joerges}

Faculty of Law, Centre of European Law and Politics, University of Bremen, Bremen, Germany.

Email: cjoerges@zerp.uni-bremen.de

Received October $19^{\text {th }}, 2011$; revised November $13^{\text {th }}, 2011$; accepted January $9^{\text {th }}, 2012$.

\begin{abstract}
The catastrophic nuclear incident in Fukushima in March 2011 has shocked Europe. Its impact was particularly strong in Germany with its decade-old anti-nuclear movements. Political and technological re-orientations were initiated in that country without considering at any depth the potential of European law and politics to control or obstruct such moves. Somewhat paradoxically, the Euratom Treaty of 1957 and also the new Treaty of Lisbon confirm the right of each Member State to decide upon the use of nuclear energy autonomously. This means that European citizens remain exposed to the risks of that technology until the highly unlikely consent of all Member States to abstain from its further use. That constellation poses a dilemma for democracy because it implies that each political decision taken within parts of the Union exerts external pan-European effects. The article considers the chances for an inclusive democratic process which would lead to a legitimated European decision. It examines the possibilities offered by the new European Citizens Initiative which the Lisbon Treaty has institutionalized in its Article 12 and concludes that this instrument could indeed be used to instigate a European-wide debate which may eventually lead to pertinent changes in the Treaties.
\end{abstract}

Keywords: Euratom Treaty; European Democratic Deficit; European Citizens Initiative; Treaty of Lisbon

\section{Introduction}

The following section of this paper, which will discuss the so-called democracy problem of the European project, might look like an overly abstract detour. It is submitted, however, that such considerations are an indispensable preparatory step towards an adequate understanding of the problems of legitimate European decision making in general as well as an evaluation of the potential of the recently institutionalized European Citizens Initiative (ECI) (Section 2) and then also for a proper interpretation of the pertinent provision in the Treaty of Lisbon and of Regulation 211/2011 (Section 4). These comments are not striving for any comprehensiveness. They will instead focus on the present particularly contested example of atomic energy (Section 3).

\footnotetext{
*Contribution to the Conference “The European Citizens' Initiative: How to get it started”, on 29 June 2011, organized by The Green/ European Free Alliance in the EP. The oral proceedings of the conference are available at:

http://www.greenmediabox.eu/archive/2011/ 06/29/eci/.
}

\section{The Compensation of Nation State Failures as Europe's Vocation}

The very idea of the ECI, as it emerged in the Convention on the Future of Europe ${ }^{1}$ and was then consolidated in the Treaty of Lisbon, was understood as an element of direct democracy which is widely recognized in principle in many constitutions. That rational is not wrong. But it seems by far too defensive. The ECI should not be understood as a strong or weak copy of national models in the US, Switzerland or elsewhere, which would contribute to the lessening of Europe democratic deficit: The ECI should instead be seen and practiced as an innovative further step through which the European Union can cure structural democracy deficits that constitutional nation states cannot overcome in isolation, as well as a step towards a transnational democratic processes which nation states

\footnotetext{
${ }^{1}$ Article 46(4)-participatory democracy; modified slightly in the Draft Constitutional Treaty (DCT) I-47 (4); see Title VI "The Democratic Life of the Union”, THE EUROPEAN CONVENTION. THE SECRETARIAT. (CONV), 650/03 of 2 April 2003 (Presidency).
} 
cannot organise in isolation.

\subsection{Democracy Deficits of Nation States}

The deficiencies of nation-state democracies stem from their inability to realize a "normative order in which those who are subject to binding legal norms should also be the normative authority that deliberates and decides about these norms in an active sense in the context of a practice of justification". ${ }^{2}$ This compensatory function of European law is of general importance. Fiscal policies of Member States and their external effects provide telling examples. The external effects of environmental policies or a lack of them are obvious. The most drastic example is atomic energy. No single Member State is able to limit the impact of its policies to those citizens who have legitimated its decisions. A democratic response to this policy issue is only conceivable at a transnational level. The organisation of such a response should be a European vocation - and precisely one which would derive its legitimacy from the compensation of the failures of national democracies.

\subsection{Potential of the New ECI}

The ECI has a distinct function. It opens perspectives for the forming of a European public, for contestation and deliberation on genuinely European matters as a background to and inspiration for European decision-making. This is not to say that it could (or should!) strive for uniformity rather "unity in diversity".

\section{The Case of Atomic Energy}

Atomic energy provides a perfect illustration for both of these points.

\subsection{Flaws of the European Treaties}

The use or non-use of this energy touches upon fundamental political and ethical issues. The democratic challenge here is obvious. No state can ensure that its deci-

\footnotetext{
${ }^{2}$ The standard formula is used by Rainer Forst [1], indebted to the same tradition and hence quite similar, e.g. J. Bohman [2] who argues: "The crucial points at which democratic legitimacy is at stake in the EU have to do with the institutional distribution of normative powers of initiative and the institutional capacity of those regularized powers and initiative and reform to the claims made by communicatively free participants in various public spheres". And shortly thereafter: The core of democratic constitutionalism is the "capacity to make the basis of democracy itself the subject of democratic deliberation of citizens “(p. 156). We can safely complement the list by nobody less than Jürgen Habermas: "Nation-states [...] encumber each other with the external effects of decisions that impinge on third parties who had no say in the decision-making process. Hence, states cannot escape the need for regulation and coordination in the expanding horizon of a world society that is increasingly self-programming, even at the cultural level [...].” Thus Habermas [3]
}

sion to use that energy affects only those who have legitimated that policy. It follows that the present institutional configuration is deeply flawed. This is so for three reasons:

- That Euratom Treaty ${ }^{3}$ assigns the power to decide upon the use or non-use of that energy to its signatories. As the ECJ has put it in Case C-29/99, the Euratom Treaty does "not give the Community the competence to regulate the opening and operation of nuclear installations". ${ }^{4}$ This is irreconcilable with the European commitments to democracy as they are solemnly confirmed in the preamble of the Treaty of Lisbon. Not only the Euratom Treaty-a Treaty which has not been impacted upon by the many important general accomplishments of the European constitutionalisation process-but also the Lisbon Treaty itself, are, in this regard, defective instruments that fail to acknowledge the transnational dimension of atomic energy. While Article 194 TFEU provides in its section $1 \mathrm{c}$ that the energy policy of the Union "shall aim, in a spirit of solidarity between Member States" to promote "the development of new and renewable forms of energy", the next section of that same Article retracts from that Europeanising step or insight. It confirms the right of Member States "to determine the conditions for exploiting its energy resources, its choice between different energy sources and the general structure of its energy supply". In view of the external effects of such decisions, that right is clearly incompatible with the Unions democratic commitments.

- There is a tension in Article 194 which will have to be addressed sooner or later and can, in the light of the preamble, gradually be resolved with due regard to European perspectives. The Euratom Treaty is of a different kind. All efforts undertaken in the context of the European Convention-such as those of Renée Wagner and the late Neil MacCormick-which sought to integrate that Treaty into the general European institutional framework ${ }^{5}$ were in vain. The attempt of five states in Declaration no. 54 to convene a Conference of the Representatives of the Governments of the Member States “as soon as possible” has not yet been realised. The silent agreement not to agree on any changes can be easily explained. "The governments of the EU member states usually strongly disagree when it comes to nuclear energy issues”. It

\footnotetext{
${ }^{3}$ The Consolidated version in Official Journal C Series (OJ C) 84 of 30 March 2010, 1.

${ }^{4}$ Case C-29/99 Commission v Council, Judgment of 10 December 2002 (Full Court), [2002] European Court Reports (ECR) I-11221, para. 63. ${ }^{5}$ See their submission to the Convention: Conv 563/03 and for an overview http://www.eu-energy.com/euratom-reform.htm. In the same vein the Editorial in (2007) 45 CMLRev 45, 929-940, at 934.
} 
took the pressures of catastrophic events such as Tschernobyl and the confrontation with Soviet-style technologies after enlargement to accomplish substantial progress $[4,5]$. The democratic problem here is that the European Union and citizens have no realistic chance to revise the decisions taken more than half a century ago on grounds which are no longer valid. Advocate General Jacobs, in his opinion in Case C-29/99, has addressed that aspect very explicitly. He noted that both the political basis, namely the unanimous trust atomic energy back in 1957, as well as scientific understanding of its risks, have changed fundamentally ${ }^{6}$-and then concludes: "As Community law stands [the Member States possess] exclusive (or virtually exclusive) competence over the technological aspects of nuclear safety". ${ }^{7}$ That conclusion can be, and has been, ${ }^{8}$ contested, or interpreted in a manner which opens the way for Community action. ${ }^{9}$ Its merit, however, is that it elucidates the second democratic deficiency of the institutional framework very clearly. The apparent autonomy of the Euratom Treaty means that the fundamental democratic right of citizens to revise the legal regime under which they live cannot be exercised. European citizens have no chance to defend themselves against an exposure to risks which they are not prepared to accept.

- A third deficiency of the present institutional constellation as it is predominantly understood comes to the fore once one considers the human rights dimensions of the exposure of citizens to the risks of atomic energy. The German Constitutional Court, in its seminal Kalkar decision of 1978, was neither prepared to prohibit the use of atomic energy because of the health risks of that technology, nor was it prepared simply to rule that citizens must live with a certain Restrisiko (remaining risk). The Court has added that the legislature shall examine "ob die ursprüngliche Entscheidung (für die Kernkraftnutzung)... aufrechtzuerhalten ist, "wenn die Entscheidungsgrundlage, durch neue, im Zeitpunkt des Gesetzerlasses noch nicht abzusehende Entwicklungen entscheidend in Frage gestellt wird" (whether the decisions to use atomic energy can

\footnotetext{
${ }^{6}$ The Para.s $137 \mathrm{ff}$.

${ }^{7}$ Opinion delivered on 13 December 2001, para. 132.

${ }^{8}$ Albeit cautiously, e.g. by P. Kautracos [6]; similarly Ch. Trüe [7], more straightforward, albeit via the detour of a right to exit from the Euratom Treaty, B. Wegener [8]; his position is by now explicitly accepted, see Article 50 TEU.

${ }^{9}$ ECJ, para. 89: "Even though the Euratom Treaty does not grant the Community competence to authorise the construction or operation of nuclear installations, under Articles 30 to 32 of the Euratom Treaty the Community possesses legislative competence to establish, for the purpose of health protection, an authorisation system which must be applied by the Member States. Such a legislative act constitutes a measure supplementing the basic standards referred to in that article.”
}

be defended in the light of unforeseen new developments). ${ }^{10}$ This duty of re-evaluation is a proceduralised response to the uncertainties of the knowledge basis of our risk assessment and management. One of the provisions of the Basic Law to which the Court referred is Article 2 (2), which has its equivalent in Article 2 of the Human Rights Charter (right to life) and on Article 14 Basic Law which has an equivalent in Article 17 (right to property), and then in Article 2 of the European Convention for the Protection of Human Rights and Fundamental Freedoms. The problem is equivalent to that of the ageing of the premises of the Euratom Treaty. ${ }^{11}$ What the German Court has spelled out, however, is a constitutional duty to revise such legislation. This is a step which is difficult to integrate into the European system because that system is not unitary. In the case of the Euratom Treaty it has explicitly been rejected in the Protocol No. 2 to the Euratom Treaty. ${ }^{12}$

\subsection{Europe's Political Deficit and the ECI}

In the case of the Euratom Treaty a deficiency becomes apparent, which enhances the much debated European democratic deficit. "Political deficit" is a term introduced by Renaud Dehousse [9] many years ago. Whereas in constitutional democracies the law is a product of processes which are democratically structured by law, this interdependence cannot develop in European arenas as long as the law blocks political debate so that the "claims made by communicatively free participants in various public spheres" cannot be transformed into binding decisions. ${ }^{13}$ The political deficit is a more general problem of the European system which stems from the fragmentation of its still nationally constituted political arenas. Precisely at this point the ECI opens up new perspectives. As Recital 8 of Regulation 211/2011 puts it, citizens' initiatives are meant "to encourage the emergence of European-wide issues and to foster reflection on those issues". The promise and perspective is not the creation of one unitary public space with uniform outcomes, but rather the interaction among a diversity of European publics. To substantiate this understanding of the democratic functions of the ECI with the help of the just cited Kalkar-decision of the German Constitutional Court: There is not one single authority instituted in the Union which would be legitimated to take a definite decision on the European-wide validity of atomic energy. What an ECI may nevertheless promote is a duty for Member

\footnotetext{
${ }^{10}$ Entscheidungen des Bundesverfassungsgerichts (German Constitutional Court) (BVerfGE) 48,89.

${ }^{11}$ Para.s 1 and 3 of the Preamble and Article 1 , once expressing a communis opinio, read today more like a provocation.

${ }^{12}$ OJ C 306/199 of 17.12.2007.

${ }^{13}$ See the citation from J. Bohman in note [2] supra.
} 
States constantly to re-evaluate their atomic commitment in the light of risk review developments.

\section{The ECI in Democratic Perspectives}

The core of the foregoing argument can be restated in generalised manner. The European citizen must be allowed to participate in political processes in which his/her concerns are debated and which can determine the binding outcome of such deliberations. This postulate implies that an ECI must be entitled to address issues of primary law. It does not imply that democratic processes in the Union must produce uniform outcomes. These processes will continue to take place primarily with in a variety of "demoi", which should, however, interact intensively and seek to implement the "principle of sincere cooperation" as laid down in Article 4 (3) TEU. The contest over atomic energy can again be used to illustrate these points.

\subsection{Primary Law and the Euratom Treaty}

The short life of the ECI has witnessed an intensive debate on the proper reading of its scope. What does the request for "a proposal for a legal act of the Union for the purpose of implementing the Treaties" encompass? ${ }^{14}$ There can be little doubt in my view that the "implementation of the Treaties" includes the promotion of the commitments and objectives spelled out therein. To cite at least one explicit confirmation: Article 48 (2) provides as an "Ordinary revision procedure" that the "government of any Member State, the European Parliament or the Commission may submit to the Council proposals for the amendment of the Treaties. These proposals may, inter alia, serve either to increase or to reduce the competences conferred on the Union in the Treaties. These proposals shall be submitted to the European Council by the Council and the national Parliaments shall be notified”. Article 106a (1) Euratom Treaty acknowledges these commitments.

The more interesting issue is whether an ECI may request a revision of the Atomic Energy Treaty and follow the example of Northrine-Westphalia. That Land has on 18 May 2011 opted for a resolution of the German Bundesrat (Federal Council of the German Länder) which should initiate a campaign for European-wide exit from atomic energy. ${ }^{15}$ The requested resolution aims at nothing less than the transformation of Euratom into an institution dedicated to the promotion of renewable energy, conceivable as a Commission initiative?

\subsection{Primary Law and the Euratom Treaty}

\footnotetext{
${ }^{14}$ The issue is comprehensively discussed in a study commissioned by the EPSU: M. Krajewski [10].

${ }^{15}$ BR-Drucksache 276/11.
}

What seems too extensive an interpretation in particular to the European Commission was once suggested by that very actor. The Commission had indeed-in its "Penelope Proposal" which was submitted in the context of the Convention Process-suggested a number of substantial changes to the Euratom Treaty. That proposal included a request to strengthen the role of the Parliament by giving it the power to adopt, together with the Council, "laws" for basic standards, whereas at present such instruments are outside the decision-making process. ${ }^{16}$

We need to add, however, that the "Penelope Proposal" was submitted in another context and cannot be invoked in the interpretation of Article 11 (4) TEU and Article 4 (2) of Regulation 211/2011.

There are nevertheless a number of positive reasons militating in favour of an extensive reading of the scope of the ECI and rejection of the claim that a provision like Article 106a (3) Euratom Treaty may, so-to-speak, unilaterally determine that the "provisions of the Treaty on European Union and of the Treaty on the Functioning of the European Union shall not derogate from the provisions of this Treaty."

While it is communis opinion that European law is bound to take continuously innovative steps so as to cope with the dynamics of the integration process, the $\mathrm{Eu}-$ ratom Treaty of 1957 gets presented as if existed in a political and legal vacuum. This is an inadequate view for a number of reasons:

- Despite of autonomy, the Treaties, the Euratom Treaty included, form one legal order. The thesis of lex specialis which accords supremacy to Euratom is far too rigid. Union objectives, such as those enshrined in Article 2 EG, now 3 TEU, also impact upon Euratom. ${ }^{17}$

- Euratom is also not exempted from Human Rights commitments. The Charter of Fundamental Rights of the European Union states in Article 6(3): "Fundamental rights, as guaranteed by the European Convention for the Protection of Human Rights and Fundamental Freedoms and as they result from the constitutional traditions common to the Member States, shall constitute general principles of the Union's law”.

- The commitments in Articles 1 and 2 Euratom Treaty to Atomic energy cannot suspend the opening of alternative options in Article 194 TFEU. $^{18}$

\subsection{Acknowledging Tensions}

Tensions and conflicts between Treaties are a very general phenomenon. This is common knowledge in inter-

\footnotetext{
${ }^{16}$ See http://www.eu-energy.com/Pages\%20from\%20penelope_en.pdf.

${ }^{17}$ Out of the contributions by Ch. Trüe see in particular [7], p. 780.

${ }^{18}$ Contrary prominently, albeit in another decade, U. Di Fabio [11].
} 
national law: it is also true for European law. There is no such thing as some genuine, self-defined or in-built supremacy of the Euratom Treaty, see [12,13]. To acknowledge tensions and conflicts does not suspend the commitment to the rule of law; they point to the domain of conflicts of laws which is dedicated to the handling of such tensions. To be sure, the notion of conflict of laws is not being used in the pertinent legal texts. But we find there helpful instructions and orienting principles:

- Article 3 TFEU provides:

1) The Union shall have an institutional framework which shall aim to promote its values, advance its objecttives, serve its interests, those of its citizens and those of the Member States, and ensure the consistency, effecttiveness and continuity of its policies and actions.

2) Each institution shall act within the limits of the powers conferred on it in the Treaties, and in conformity with the procedures, conditions and objectives set out in them. The institutions shall practice mutual sincere cooperation.

- The commitment to democracy and human rights were mentioned above.

It is important to realise that the response to a conflict need not to be found in a uniform answer. "Unity in diversity", the fortunate motto of the otherwise not so fortunate Draft Constitutional Treaty points in the proper direction. To put it in very mundane terms: The French are not entitled to expose the Germans to the risks of nuclear energy. The same is true vice versa: The Germans cannot impose their Energiewende on the rest of Europe. Are we back at the beginning of our deliberations? Is the European democratic deficit at the end of the day purely an irresolvable dilemma?

\subsection{The Primacy of Politics and the Search for Mediating Initiatives}

Tertium datur. Atomic energy confronts us with fundamental difficulties. It took the Germans decades of political contestation before they concluded "after Fokushima" that their Ausstieg is politically opportune, economically and technologically feasible. There are many reasons for other societies not to follow that example. As I have argued above, atomic energy is a problem which should not be delegated to expert circles, intergovernmental bargaining or the law, not even to the European Court of Justice. ${ }^{19}$ Atomic Energy policy needs to be embedded in legitimating political processes. Such processes are unlikely to end in European-wide uniformity. They may, however, promote mutual understanding and the readiness to take serious concerns of neighbouring

\footnotetext{
${ }^{19}$ See my critique of the Temelin judgment, Case C-115/08, Oberösterreich v. CEZ as, [ECR] 2009 I-10265: Joerges [14]; surprisingly similar S. Wolf [4].
}

societies neighbouring societies seriously. This is why the request of the Land Northrine-Westphalia for strong safety standards deserves recognition. It seems to me that the European Commission has understood these lessons. This I infer from the recent proposal for a Directive on energy efficiency ${ }^{20}$ and the Communication on renewable energy. ${ }^{21}$ All that are not to say that ECIs which seek to promote such innovative moves would have become superfluous. But it is nice to conclude with an optimistic outlook.

\section{REFERENCES}

[1] R. Forst, “Transnational Justice and Democracy,” 2011. http.//ww.reconproject.eu/main.php/RECON_wp_1112.p df?fileitem?5456467

[2] J. Bohman, "Democracy across Borders: From Dêmos to Dêmoi,” MIT Press, Cambridge, 2007, pp. 135-152.

[3] J. Habermas, "Does the Constitutionalization of International Law Still Have a Chance?” In: J. Habermas, Ed., The Divided West, Polity Press, Cambridge, 2007, pp. 113-193.

[4] S. Wolf, "Euratom, the European Court of Justice and the Limits of Nuclear Integration in Europe," German Law Journal, Vol. 12, No. 8, 2011, pp. 1637-1657.

[5] R. Sauter, "EU-Agenda-Setting und Europäische Energiepolitik: Das 'EU-Nuklearpaket',” Österreichische Zeitschrift für Politikwissenschaft, Vol. 38, No. 4, 2009, pp. 453463.

[6] P. Kautracos, “Case Annotations," Common Market Law Review, Vol. 41, 2004, pp. 191-208.

[7] C. Trüe, "EU-Kompetenzen für Energierecht, Gesundheitsschutz und Umweltschutz nach dem Verfassungsentwurf," Juristenzeitung, Vol. 59, No. 15-16, 2004, pp. 779-791.

[8] B. Wegener, "Die Kündigung des Vertrages zur Gründung der Europäischen Atomgemeinschaft (EURATOM),” 2007.

http://www.gruene-bundestag.de/cms/archiv/dokbin/170/ 170871.reader_euratom_gutachten_im_auftrag_der.pdf

[9] R. Dehousse, "Constitutional Reform in the European Community: Are there Alternatives to the Majoritarian Avenue?” West European Politics, Vol. 18, No. 3, 1995, pp. 118-136. doi:10.1080/01402389508425094

[10] M. Krajewski, “Legal Framework of a European Citizens' Initiative for a European Right to Water,” Bremen-Erlangen, on file with author, 2010.

[11] U. Di Fabio, "Der Ausstieg aus der Wirtschaftlichen Nutzung der Kernenergie: Europarechtliche und Verfassungsrechtliche Vorgaben,” Carl Heymanns Verlag, Cologne, 1999.

[12] Th. F. Cusack, "A Tale of Two Treaties: An Assessment of the Euratom Treaty in Relation to the EC Treaty," Common

\footnotetext{
${ }^{20}$ See European Commission Communication (COM) (2011) 370 final of 22.6.2011.

${ }^{21} \mathrm{COM}$ (2011) 31 final of 31.1.2011.
} 

Institutionalisation of the European Citizens' Initiative in the Lisbon Treaty

Market Law Review, Vol. 40, 2003, pp. 117-142.

[13] S. Wolf, “Zur Zukunft des Euratom-Vertrags,” integration, Vol. 29, No. 4, 2006, pp. 297-302.

[14] C. Joerges, “Unity in Diversity as Europe’s Vocation and
Conflitcs Law as Europe's Constitutional Form,” 2010. http://papers.ssrn.com/sol3/papers.cfm?abstract_id?=1723 249. 